\title{
Far-red and Blue Light Synergistically Mitigate Intumescence Injury of Tomato Plants Grown Under Ultraviolet-deficit Light Environment
}

\author{
Tomomi Eguchi, Ricardo Hernández ${ }^{1}$, and Chieri Kubota ${ }^{2}$
}

School of Plant Sciences, The University of Arizona, Tucson, AZ 85721-0036

Additional index words. blue light, edema, end-of-day, far-red light, LED, light quality, oedema, Solanum lycopersicum, Solanum habrochaitas, transplants

\begin{abstract}
Intumescence injury is an abiotic-stress-induced physiological disorder associated with abnormal cell enlargement and cell division. The symptom includes blister- or callus-like growths on leaves, which occur on sensitive cultivars of tomato when they are grown under ultraviolet (UV)-deficit light environment, such as light-emitting diodes (LEDs). Previous studies suggest that intumescence can be reduced by increasing far-red (FR) or blue light. In the present study, effects of end-of-day FR (EOD-FR) light and high blue photon flux (PF) ratio during the photoperiod on intumescence injury were examined using 'Beaufort' interspecific tomato rootstock seedlings (Solanum lycopersicum $\times$ Solanum habrochaites), a cultivar highly susceptible to intumescence injury. Our study showed that EOD-FR light treatment moderately suppressed intumescence injury. Using EOD-FR light treatment, the percent number of leaves exhibiting intumescences was reduced from $62.0-70.7 \%$ to $39.4-43.1 \%$. By combining high blue PF ratio $(75 \%)$ during the photoperiod and EOD-FR light treatment, the percent number of leaves exhibiting intumescences was further suppressed to $5.0 \%$. Furthermore, the combination of high blue PF ratio and EOD-FR light treatment inhibited undesirable stem elongation caused by EOD-FR light treatment. We found that high blue $P F$ ratio during the photoperiod combined with a small dose of EOD-FR lighting $\left(\approx 1 \mathrm{mmol} \cdot \mathrm{m}^{-2} \cdot \mathrm{d}^{-1}\right.$ provided by $5.2 \mu \mathrm{mol} \cdot \mathrm{m}^{-2} \cdot \mathrm{s}^{-1}$ FR PF for 3.3 minutes) could inhibit the problematic intumescence injury of tomato plants grown under LEDs without negatively influencing growth or morphology.
\end{abstract}

Intumescence injury, also known as edema or oedema is a nonpathogenic physiological disorder characterized visually by abnormal, blister- or callus-like tumor growths that predominantly develop on the surface of leaves and sometimes on petioles and stems (Fig. 1A and B). Intumescence injury has been observed on many plant species such as white popular (Populus grandidentatal) (La Rue, 1933), eggplant (Solanum melongena) (Eisa and Dobrenz, 1971), sweetpotato (Ipomoea batatas) (Wetzstein and Frett, 1984), potato (Solanum tuberosum) (Petitte and Ormrod, 1986), tomato (S. lycopersicum and S. habrochaites) (Lang et al., 1983), ivy geranium (Pelargonium peltatum) (Rangarajan and Tibbitts, 1994), and blue gum (Eucalyptus globulus) (Pinkard et al., 2006). The tumor growths are mostly produced

Received for publication 15 Jan. 2016. Accepted for publication 5 Apr. 2016.

This project was funded by USDA NIFA SCRI (award number 2010-51181-21369).

We thank CCS Inc., Orbital Technologies Inc., and Monsanto Co. (De Ruiter Seeds) for generously providing the LED systems and seeds used in our study.

${ }^{1}$ Current affiliation: Department of Horticulture, North Carolina State University, Raleigh, NC.

${ }^{2}$ Corresponding author. E-mail: ckubota@e-mail. arizona.edu. by abnormal enlargement (hypertrophy) of parenchyma or both parenchyma and epidermal cells (Balge et al., 1969; Douglas, 1907; Eisa and Dobrenz, 1971; Lang et al., 1983; La Rue, 1933), although a combination of hypertrophy and abnormal division (hyperplasia) of those cells are sometimes observed in some species and cultivars (Craver et al., 2014; Pinkard et al., 2006; Wetzstein and Frett, 1984). In severe cases, the hypertrophied cells ultimately cause the rupture (Lang et al., 1983) or collapse of epidermal cells (Craver et al., 2014), resulting

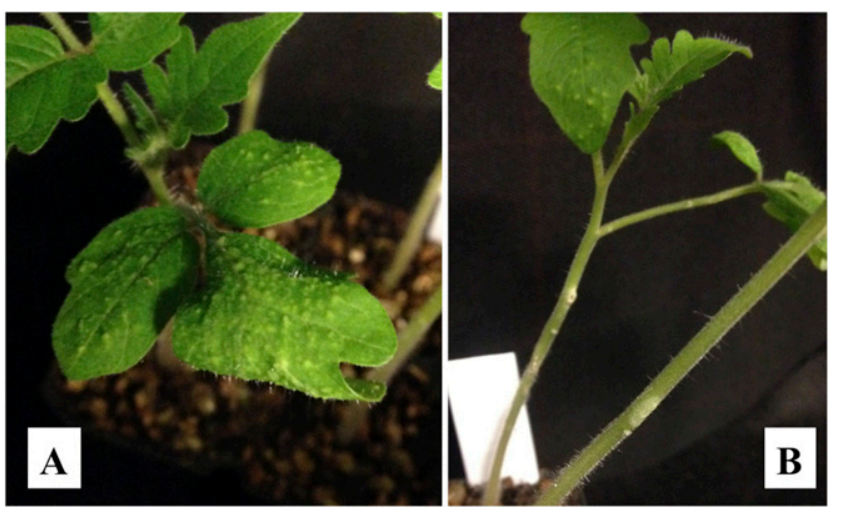

Fig. 1. Intumescence injury on tomato seedlings grown under blue and red light-emitting diodes. (A) Blister-like tumor growths on a leaf. (B) Callus-like tumor growths on stems. in necrosis of leaf tissue and leaf abscission (Lang and Tibbitts, 1983; Rangarajan and Tibbitts, 1994)

Previous studies indicated that humidity and light quality contributed to regulation of intumescence development (Eisa and Dobrenz, 1971; Lang and Tibbitts, 1983; Metwally et al., 1970; Warrington, 1980). For example, in ivy geranium (P. peltatum) (Metwally et al., 1970), eggplant ( $S$. melongena) (Eisa and Dobrenz, 1971), and potato (S. tuberosum) (Douglas, 1907), high relative humidity, high root medium water content, or the combination of those environments induced or promoted intumescence development. Therefore, in those species, intumescence injury was suggested as primarily caused by excessive turgor, which occurs when high relative humidity reduces transpiration. However, Lang and Tibbitts (1983) found that severe symptoms of intumescence injury were observed in tomato regardless of relative humidity ( 30 vs. $92 \%$ ).

Light quality has been indicated as a primary factor regulating intumescence development in tomato (Lang and Tibbitts, 1983) and sweetpotato (Craver, 2014), although underlying mechanisms remain poorly understood. Ultraviolet radiation, especially UV-B radiation (280-320 $\mathrm{nm}$ ) has reportedly inhibited intumescence development (Craver et al., 2014; Lang and Tibbitts, 1983). For example, Lang and Tibbitts (1983) found that intumescence development on tomato was severe when the low irradiance of UV-B from cool white fluorescent lamps (WFL) was blocked.

We have observed intumescence injury in some cultivars of tomato rootstocks seedlings, such as interspecific tomato rootstock 'Beaufort' and 'Maxifort' (S. lycopersicum $\times$ $S$. habrochaites), when they are cultivated in indoor production systems under electric lighting, especially under LEDs, which are typically UV deficient. A similar observation was reported for pepper suggesting intumescence injury may limit the use of LEDs for indoor production systems (Massa et al., 2008). Under UV-deficient light quality, Morrow (1987) and Morrow and Tibbitts (1988) indicated the involvement of phytochrome in regulation of 
intumescence development in tomato. Leaf discs of wild tomato ( $S$. habrochaites) developed intumescence under red light (600-700 nm) but not under combinations of red and FR (700-800 nm) (Morrow, 1987). Also, the same study reported that intumescence development was a red-FR reversible response in which intumescence development was inhibited by providing FR light immediately following red light. Hence, FR light may reduce intumescence injury in whole plants when applied at the EOD following a photoperiod with intumescenceinducing light quality, but the effective intensity and dose of FR light are not well characterized.

Phytochromes are photoreceptor proteins, with two interconvertible isoforms $P_{\mathrm{r}}$ (inactive isoform) and $P_{\mathrm{fr}}$ (active isoform), that have peak absorption in red and FR light (Hendricks et al., 1962; Siegelman et al., 1966). The phytochrome isoform ratio of $P_{\mathrm{r}}$ and $P_{\mathrm{fr}}$ is changed by irradiation with red or FR light, resulting in altered biochemical and physiological responses such as germination (Mancinelli et al., 1966), stem elongation, and pigment synthesis (Hendricks and Borthwick, 1967). Some plant responses can be elicited by a low red to FR ratio during the photoperiod or short-duration FR light applied only at EOD, which alters the ratio of $P_{\text {fr }}$ during photoperiod or the dark period (Fankhauser and Casal, 2004; Mancinelli, 1994; Smith, 1994). For example, promotion of stem elongation by low red to FR ratio during the photoperiod or by EOD-FR light was confirmed among many species (Demotes-Mainard et al., 2016).

In addition to UV-B and FR light, blue $(400-500 \mathrm{~nm})$, and green $(500-600 \mathrm{~nm})$ light have been found to prevent intumescence development of tomato when they were substituted for some or all of red light (Wollaeger and Runkle, 2014). 'Early Girl' tomato plants grown under LEDs with at least $50 \%$ blue PF ratio had nearly no intumescence injury (Wollaeger and Runkle, 2014). In a preliminary study, we found that the incidence of intumescence injury on leaves of 'Beaufort' tomato rootstock plants decreased linearly with increasing blue PF ratio from $10 \%$ to $75 \%$ (Hernández et al., unpublished data). However, the highest blue PF ratio did not completely eliminate the intumescence injury, suggesting the need of further optimization.

Therefore, in the present study, first, EOD-FR light treatment was examined as a means to inhibit intumescence injury of tomato plants grown under UV-deficient light (Expt. 1). Second, we examined the relationship between intumescence injury and daily EOD-FR dose, in which the daily minimum dose (intensity $\times$ duration) required to maximally inhibit intumescence injury, was quantified (Expt. 2). Finally, combination of high blue PF ratio during the photoperiod and EOD-FR light was examined for intumescence injury, plant growth, and morphology (Expt. 2).

\section{Materials and Methods}

\section{Plant materials and growth conditions}

The tomato rootstock cultivar Beaufort (De Ruiter Seeds, Bergshenhoek, The Netherlands) used in this study is highly sensitive to intumescence-inducing environments. A total of 32 seeds for each treatment were sown into a $14.5 \mathrm{~cm} \times 29.4 \mathrm{~cm}$ cut-out section of 98 -cell seedling tray $(28.0 \mathrm{~cm} \times 53.8 \mathrm{~cm})$ filled with moist commercial substrate (Sunshine Professional Mix 3; Sun Gro Horticulture, Agawam, MA) and covered with a thin layer of vermiculite. The seeded trays were placed in a growth chamber (Model 2015; VWR International, Radnor, PA) controlled at $28 \pm 1{ }^{\circ} \mathrm{C}$ air temperature under darkness for $1 \mathrm{~d}$ until radicles emerged. The trays were then transferred to a walk-in growth chamber (floor area: $14.8 \mathrm{~m}^{2}$ ) set at $25{ }^{\circ} \mathrm{C}$, and placed under designated light treatments described below. Out of 32 plants, 12 plants, surrounded by 20 plants (border plants), were subjected to measurements described below. The plants were subirrigated as needed through the experiments with nutrient solution (EC 1.9 to $2.1 \mathrm{dS} \cdot \mathrm{m}^{-1}, \mathrm{pH} 5.9$ to 6.1 ) containing $90 \mathrm{mg} \cdot \mathrm{L}^{-1}$ nitrogen (all in nitrate form), $47 \mathrm{mg} \cdot \mathrm{L}^{-1}$ phosphorus, $144 \mathrm{mg} \cdot \mathrm{L}^{-1}$ potassium, $160 \mathrm{mg} \cdot \mathrm{L}^{-1}$ calcium, $60 \mathrm{mg} \cdot \mathrm{L}^{-1}$ magnesium, and $113 \mathrm{mg} \cdot \mathrm{L}^{-1}$ sulfur as well as micronutrients. Air temperature measured directly under the leaves was recorded for each treatment with fine-wire thermocouples (type T, gauge 36; Omega Inc., Stamford, CT). Relative humidity and $\mathrm{CO}_{2}$ concentration were measured in the middle of the growth chamber using a humidity sensor (HMP110; Vaisala Inc., Helsinki, Finland) and a $\mathrm{CO}_{2}$ analyzer (LI-800; LI-COR Biosciences, Lincoln, NE). All sensors were connected to a CR-23X datalogger (Campbell Scientific, Logan, UT) scanned every $5 \mathrm{~s}$ and recorded at 5-min intervals. The growth chamber was also equipped with a $\mathrm{CO}_{2}$ injection system to ensure that the $\mathrm{CO}_{2}$ concentration was maintained above $400 \mu \mathrm{mol} \cdot \mathrm{mol}^{-1}$. Photoperiod was $18 \mathrm{~h}$ in all experiments.

\section{Light treatment}

Light sources used for photosynthetic lighting were cool WFL (F40T12 CW Supreme ALTO Plus; Philips Lighting, Somerset, NJ) or LED panels $(35 \times 34 \mathrm{~cm}$; CCS Inc., Kyoto, Japan) with blue and red LEDs [peak wavelength 455 and $661 \mathrm{~nm}$, full width at half maximum (FWHM): 15 and $20 \mathrm{~nm}$, respectively], connected to a digital controller (ISC-101-4; CCS Inc.) capable of controlling output of blue and red LEDs independently. For EOD-FR light treatment, a FR LED panel $(16 \times 16 \mathrm{~cm}$; CCS Inc.; peak wavelength $738 \mathrm{~nm}$, FWHM: $26 \mathrm{~nm}$ ) (Expts. 1 and 2$)$ or FR LED bars $(122 \times 1.5 \mathrm{~cm}$; Orbital Technologies Inc., Madison, WI; peak wavelength $743 \mathrm{~nm}$, FWHM: $31 \mathrm{~nm}$ ) (Expt. 2) were used.

Compartments $(114 \mathrm{~cm} \times 46 \mathrm{~cm} \times 91 \mathrm{~cm})$ were created inside the growth chamber to separate light treatments using standard shelving units. Black cloth was put between compartments to prevent light contamination. The light fixtures were placed horizontally $8-14 \mathrm{~cm}$ (cool WFL and blue and red LED panels) or 14-30 cm (FR LED panel and bars) above the plant canopy. The distance between the light fixtures and the plant canopy was adjusted throughout the experiment to maintain the designated PF levels at the top of the canopy. PFs were measured on five locations in each plant-growth area using a spectroradiometer (PAR-NIR; Apogee Instruments Inc., Logan, UT). Table 1 shows the summary of light treatments of the two experiments.

Expt. 1: Effect of EOD-FR light on intumescence injury, growth, and morphology of tomato plants under low blue $P F$ ratio. The plants were grown under $69 \pm 2 \mu \mathrm{mol} \cdot \mathrm{m}^{-2} \cdot \mathrm{s}^{-1}$ photosynthetic photon flux $(P P F)$ using blue and red LEDs with $10 \%$ blue ( $90 \%$ red) PF ratio (10B-90R\% treatment) or cool WFL with blue, green, and red PF ratios of 20:49:31 (WFL treatment). The relatively low $P P F$ was due to the limitation in achieving higher $P P F$ under the facility conditions applied to Expt. 1. After $5 \mathrm{~d}$ from seeding when cotyledons were emerged, half of plants grown under 10B-90R\% LEDs were subjected to daily EOD-FR light treatments at the dosage of $67.2 \pm 2.4 \mathrm{mmol} \cdot \mathrm{m}^{-2}$, achieved by $66 \mu \mathrm{mol} \cdot \mathrm{m}^{-2} \cdot \mathrm{s}^{-1} \mathrm{FR}$ PF for $17 \mathrm{~min}\left(10 \mathrm{~B}-90 \mathrm{R} \% \mathrm{o}^{-}\right.$ EOD-FR treatment). This high level of FR was selected to assure the maximum response as the dose response was unknown. The seedlings trays were manually moved to the compartment with FR LEDs right after every photoperiod for EOD-FR light treatment.

Expt. 2: EOD-FR light at varied doses and high blue PF ratio during the photoperiod on intumescence injury, growth, and morphology of tomato plants. The plants were grown under $102 \pm 3 \mu \mathrm{mol} \cdot \mathrm{m}^{-2} \cdot \mathrm{s}^{-1} \mathrm{PPF}$ using blue and red LEDs with $10 \%$ blue PF (10B-90R\% treatment) or $75 \%$ blue PF (75B-25R $\%$ treatment) ratio. After $4 \mathrm{~d}$ from seeding when cotyledons were emerged, varied doses $(0$, $1.1,2.1,4.2,9.4$, or $\left.76.0 \mathrm{mmol} \cdot \mathrm{m}^{-2} \cdot \mathrm{d}^{-1}\right)$ of EOD-FR light were applied daily to the plants grown under $10 \mathrm{~B}-90 \mathrm{R} \%$ or $75 \mathrm{~B}-25 \mathrm{R} \%$ treatments, respectively. The FR PF and durations to achieve these EOD-FR light doses are shown in Table 1.

\section{Measurements}

After 18 (Expt. 1) and 16 d (Expt. 2) from seeding, the plants were harvested to evaluate for intumescence injury, growth, and morphology. Plants were visually assessed for development of intumescences (gall-like tumors) on leaves, development of intumescences (callus-like tumors) on stem and leaf abscission. The number of leaves with and without intumescences and the percent number of leaves exhibiting intumescences was recorded for each plant. In addition, every fully expanded true leaf (first to third leaves from the bottom) of each plant was visually rated for the severity of intumescence injury on the adaxial leaf surface with a scale of 1 to 6: namely, 1) no intumescence injury, 
Table 1. Summary of the light treatments applied in the experiments (Expts. 1 and 2). Blue and red photon flux ratio (B:R PF ratio), average photosynthetic photon flux $(P P F)$, ultraviolet (UV)-B radiation intensity (UV-B PF), and phytochrome photoequilibrium $\left(P_{\mathrm{fr}} / P\right)$ (Sager et al., 1988) of photosynthetic lighting, and $P_{\mathrm{fr}} / P$, far-red light intensity (FR PF), duration, and FR dose of EOD-FR light treatment are shown. UV-B, blue, red, and FR PF were integrated over 250-320 nm, 400-500 nm, 600-700 nm, and 700-800 nm, respectively. In Expt. 1, 'Beaufort' tomato plants were grown under cool white fluorescent lamps (WFL treatment) or 10B-90R\% light-emitting diodes (LEDs) without or with high dose of EOD-FR light treatment ( $\left.67 \mathrm{mmol} \cdot \mathrm{m}^{-2}\right)$. In Expt. 2 , 'Beaufort' tomato plants were grown under 10B-90R $\%$ or $75 \mathrm{~B}-25 \mathrm{R} \%$ LEDs without or with varied daily dose of EOD-FR light treatment $\left(1-76 \mathrm{mmol} \cdot \mathrm{m}^{-2}\right)$.

\begin{tabular}{|c|c|c|c|c|c|c|c|c|}
\hline \multirow[b]{2}{*}{ Light treatment } & \multicolumn{4}{|c|}{ Phtotosynthetic lighting } & \multicolumn{4}{|c|}{ EOD-FR light treatment } \\
\hline & $\begin{array}{l}\mathrm{B}: \mathrm{R} P \mathrm{PF} \\
\text { ratio }(\%)\end{array}$ & $\begin{array}{l}P P F(400-700 \mathrm{~nm}) \\
\quad\left(\mu \mathrm{mol} \cdot \mathrm{m}^{-2} \cdot \mathrm{s}^{-1}\right)\end{array}$ & $\begin{array}{c}\text { UV-B PF } \\
(250-320 \mathrm{~nm}) \\
\left(\mu \mathrm{mol} \cdot \mathrm{m}^{-2} \cdot \mathrm{s}^{-1}\right)\end{array}$ & $P_{\mathrm{fr}} / P$ & $P_{\mathrm{fr}} / P$ & $\begin{array}{c}\text { FR PF } \\
(700-800 \mathrm{~nm}) \\
\left(\mu \mathrm{mol} \cdot \mathrm{m}^{-2} \cdot \mathrm{s}^{-1}\right)\end{array}$ & $\begin{array}{l}\text { Duration } \\
\text { (min) }\end{array}$ & $\begin{array}{c}\text { FR dose } \\
\left(\mathrm{mmol} \cdot \mathrm{m}^{-2} \cdot \mathrm{d}^{-1}\right)\end{array}$ \\
\hline 10B-90R\% & $10: 90$ & $68.4 \pm 1.8$ & 0 & 0.886 & - & 0 & - & 0 \\
\hline 10B-90R\%-EOD-FR & $10: 90$ & $68.7 \pm 2.2$ & 0 & 0.886 & 0.113 & $65.9 \pm 2.4$ & 17 & $67.2 \pm 2.4$ \\
\hline \multicolumn{9}{|l|}{ Expt. 2} \\
\hline 10B-90R\%-FR2 & $10: 90$ & $102.8 \pm 3.8$ & 0 & 0.886 & 0.121 & $5.3 \pm 0.2$ & 6.5 & $2.1 \pm 0.1$ \\
\hline 10B-90R\%-FR4 & 10:90 & $102.3 \pm 2.9$ & 0 & 0.886 & 0.119 & $14.9 \pm 0.6$ & 4.7 & $4.2 \pm 0.2$ \\
\hline 10B-90R\%-FR9 & $10: 90$ & $102.0 \pm 2.7$ & 0 & 0.886 & 0.122 & $16.8 \pm 1.0$ & 9.4 & $9.4 \pm 0.6$ \\
\hline 10B-90R\%-FR76 & $10: 90$ & $101.9 \pm 1.9$ & 0 & 0.886 & 0.113 & $74.5 \pm 4.9$ & 17 & $76.0 \pm 5.0$ \\
\hline $75 \mathrm{~B}-25 \mathrm{R} \%$ & $75: 25$ & $100.4 \pm 0.8$ & 0 & 0.830 & - & 0 & - & 0 \\
\hline 75B-25R\%-FR4 & $75: 25$ & $100.0 \pm 0.7$ & 0 & 0.832 & 0.119 & $14.9 \pm 0.6$ & 4.7 & $4.2 \pm 0.2$ \\
\hline
\end{tabular}

${ }^{\mathrm{z}}$ Dose was the product of FR photon flux and duration of the treatment.

${ }^{\mathrm{y}}$ White fluorescent lamps had a blue, green, and red ratio of 20:49:31.

2) intumescences covering less than $10 \%$ area, 3) intumescences covering $10 \%$ to $50 \%$ area, 4) intumescences covering $50 \%$ to $75 \%$ area, showing minor epinasty, 5) intumescences covering $75 \%$ to $100 \%$ area, showing severe epinasty, and 6) leaf abscission.

Stem length and hypocotyl length were measured using a ruler. Shoot fresh and dry weights were measured using an electronic balance. Leaf number per plant for leaves greater than $1 \mathrm{~cm}$ in length were counted and recorded. Images of leaves and cotyledons were obtained using a scanner and leaf area per plant was calculated using the LIA 32 software for leaf area analysis (Nagoya University, Nagoya, Japan). Plant shoots were transferred into a drying oven at $80{ }^{\circ} \mathrm{C}$ for at least $48 \mathrm{~h}$ to obtain the shoot dry weight.

\section{Experimental design and statistical analysis}

The experiment was conducted once for Expt. 1 (9-27 Oct. 2014) and twice for Expt. 2 (3-19 Dec. 2014 and 24 Jan.-9 Feb. 2015) (except for $75 \mathrm{~B}-25 \mathrm{R} \%$ without EOD-FR light treatment, once). Data of two replications were pooled in Expt. 2 as there were no interactions found between replications. Each replication had 12 plants per treatment. The treatment locations inside the growth chamber were randomly mixed between replications to minimize position effects within the growth chamber. Within the same treatment, the positions of plants were systematically rotated every day to improve the uniformity of light environment. JMP Pro (version 11; SAS Institute Inc., Cary, NC) was used to analyze the data. Analysis of variance $(P=$ 0.05 ) was performed to identify any difference among treatments. Mean separations were analyzed using Tukey's honestly significant difference test. For incidence data (the incidence of intumescences on stem and leaf abscission), Tukey's wholly significant different test $(P=0.05)$ was used.

\section{Results}

Environmental conditions. Average day/ night air temperatures measured directly under the leaves of each treatment were $25.2 \pm 0.4$ / $25.2 \pm 0.4{ }^{\circ} \mathrm{C}$ in Expt. 1 and $25.1 \pm 0.6 / 24.9 \pm$ $0.5^{\circ} \mathrm{C}$ in Expt. 2. The average difference in day/night temperatures between treatments was less than $0.3 / 0.1^{\circ} \mathrm{C}$ in Expt. 1 and 0.3 / $0.3{ }^{\circ} \mathrm{C}$ in Expt. 2. Average relative humidity measured in the middle of the growth chamber was $56.9 \pm 5.3 \%$ in Expt. 1 and $53.0 \pm 6.9 \%$ in Expt. 2. Average atmospheric $\mathrm{CO}_{2}$ concentration measured in the middle of the growth chamber was $509 \pm 48 \mu \mathrm{mol} \cdot \mathrm{mol}^{-1}$ in Expt. 1 and $512 \pm 74 \mu \mathrm{mol} \cdot \mathrm{mol}^{-1}$ in Expt. 2.

Effects of EOD-FR light on intumescence injury, growth, and morphology of tomato plants under low blue PF ratio (Expt. 1). As expected, the plants grown under cool WFL (WFL treatment) did not develop intumescences during the experiment. In contrast, the plants grown under LEDs with $10 \%$ blue PF ratio without EOD-FR light (10B-90R\% at $0 \mathrm{mmol} \cdot \mathrm{m}^{-2} \cdot \mathrm{d}^{-1}$ dose, Fig. 2) were severely injured by intumescences.

The high dose of EOD-FR light at 67.2 $\mathrm{mmol} \cdot \mathrm{m}^{-2} \cdot \mathrm{d}^{-1}$ under $10 \%$ blue PF ratio reduced the percent number of leaves exhibiting intumescences from $70.7 \%$ to $39.4 \%$ (Fig. 2A). The EOD-FR light also decreased the visual assessment scores for severity of intumescence injury on first and second leaf from 5.4 to 4.0 and 4.3 to 3.3 , respectively (Fig. 2A and C). The severity of intumescence injury was also mitigated for third true leaf by the EOD-FR light (from 2.3 to 1.1, data not shown); however, these low levels of intumescence injury (around or less than 10\% of leaf area) may be acceptable. The EOD-FR light also reduced the incidence of intumescences on stem and leaf abscission from
$100.0 \%$ to $0.0 \%$ and from $41.7 \%$ to $0.0 \%$, respectively, for the plants grown under $10 \%$ blue PF ratio (Table 2).

The $10 \%$ blue PF ratio largely suppressed the plant growth (Table 3). However, EOD-FR light improved plant growth under $10 \%$ blue $\mathrm{PF}$ ratio up to the same level as those in WFL treatment. Fresh weight, leaf number, and leaf area under $10 \%$ blue PF ratio with EOD-FR light treatment were significantly increased compared with those without EOD-FR light treatment by $80 \%, 31 \%$, and $67 \%$, respectively. In contrast, stem length and hypocotyl length were significantly increased under EOD-FR light treatment compared with those under $10 \mathrm{~B}-90 \mathrm{R} \%$ ratio treatment or WFL treatment by $33 \%$ or $80 \%$ and $40 \%$ or $150 \%$, respectively. This increased stem growth is generally not welcomed in transplant production as plants tend to lodge and do not establish well after transplanting. No significant different was observed among treatments for shoot dry weight.

Effect of EOD-FR light at varied doses and high blue PF ratio during the photoperiod on intumescence injury, growth, and morphology of tomato plants (Expt. 2). Similar to what was observed in Expt. 1, the plants grown under $10 \%$ blue PF ratio without EOD-FR light (10B$90 \mathrm{R} \%$ at $0 \mathrm{mmol} \cdot \mathrm{m}^{-2} \cdot \mathrm{d}^{-1}$ dose, Fig. 2) were severely injured by intumescences. EOD-FR light suppressed intumescence injury regardless of FR light dose $\left(1.1\right.$ to $\left.76.0 \mathrm{mmol} \cdot \mathrm{m}^{-2} \cdot \mathrm{d}^{-1}\right)$ (Fig. 2). The percent number of leaves exhibiting intumescences was significantly reduced by the EOD-FR light from $62.0 \%$ to $39.4 \%$ to $43.1 \%$. The EOD-FR light also significantly reduced the severity of intumescence injury on first and second true leaf, from 5.5 to $4.1-4.6$, and from 4.4 to $2.9-3.5$, respectively (Fig. 2B and $\mathrm{C}$ ). The severity for the third leaf was at an acceptable level ( $10 \%$ or less leaf area), but the reduction of the severity score by the EOD-FR light was also significant (data not shown). Intumescences on stem and leaf abscission 

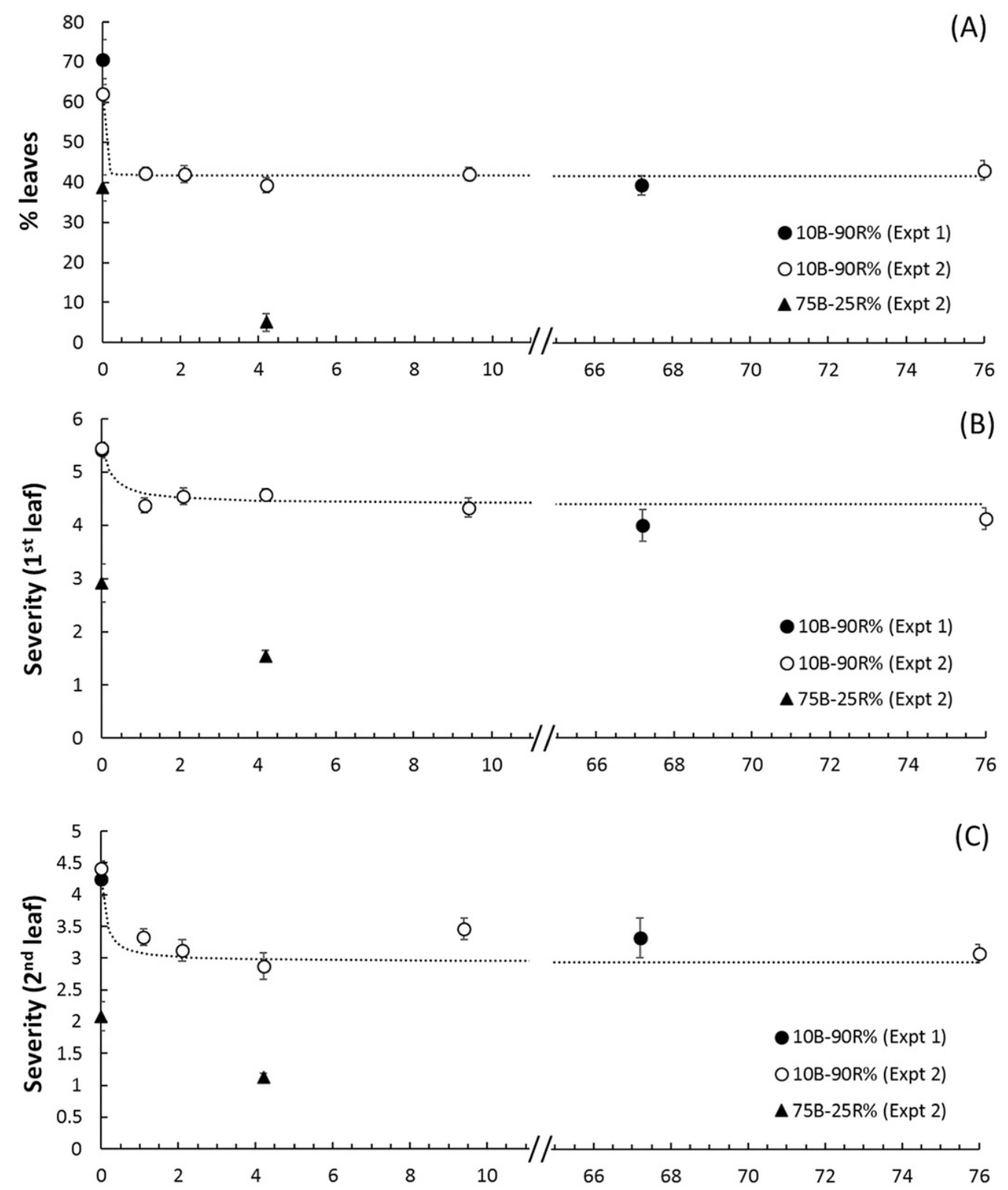

\section{End-of-day far-red dose $\left(\mathrm{mmol} \cdot \mathrm{m}^{-2} \cdot \mathrm{d}^{-1}\right)$}

Fig. 2. Effect of end-of-day far-red (EOD-FR) light dose on (A) percent number of leaves exhibiting intumescences (IMs) per plant (\% leaves with IMs), (B) severity of IM injury of first true leaf, and (C) second true leaf [rating scale of 1 to 6: $1=$ no IM injury, $2=$ IMs covering less than 10\% area, $3=\mathrm{IMs}$ covering $10 \%$ to $50 \%$ area, $4=$ IMs covering $50 \%$ to $75 \%$ area, showing minor epinasty, $5=$ IMs covering $75 \%$ to $100 \%$ area, showing severe epinasty, $6=1$ eaf abscission (most severe)] when 'Beaufort' tomato rootstock plants were grown under low blue photon flux (PF) (10B-90R\%) or high blue PF (75B-25R\%) in two experiments (see Table 1). A trend line using a Michaelis-Menten type model was applied in each response to EOD-FR dose under 10B-90R\% LEDs (Expt. 2). Means are shown with standard errors $(\mathrm{n}=12$ or 24$)$.

were absent or nearly absent when the plants were grown with EOD-FR light regardless of FR light dose, whereas $62.5 \%$ and $54.2 \%$ of the plants exhibited intumescences on stem and leaf abscission, respectively, when the plants were grown without EOD-FR light (Table 2).

When the plants were grown under high blue PF ratio $(75 \%)$ without EOD-FR light, the percent number of leaves exhibiting intumescences was reduced from $62.0 \%$ to $38.6 \%$, and the severity of intumescence injury on first and second leaf were significantly reduced from 5.5 to 2.9 and 4.4 to 2.1 , respectively, compared with those under low blue PF ratio (10B-90R\%) without EOD-FR light (Fig. 2). Under the high blue PF ratio (75B-25R\%, Table 2), incidence of intumescences on stem was reduced from $62.5 \%$ to $16.7 \%$ and leaf abscission was reduced from $54.2 \%$ to $8.3 \%$, compared with those under low blue PF ratio (10B-90R\%). The plants grown under the combination of high blue $\mathrm{PF}$ ratio and EOD-FR light $\left(4.2 \mathrm{mmol} \cdot \mathrm{m}^{-2} \cdot \mathrm{d}^{-1}\right)$ had the lowest percent number of leaves exhibiting intumescences $(5.0 \%)$, and the least severity of intumescence injury on first and second leaf (1.5 and 1.1, respectively) among all treatments in Expt. 2 (Fig. 2).
Shoot fresh weight, hypocotyl length, and stem length of the plants grown under high blue PF ratio with EOD-FR light (75B-25R\%FR4 treatment) was $31 \%, 46 \%$, and $43 \%$ lower that under low blue PF ratio with EOD-FR light (10B-90R\%-FR4 treatment) (Fig. 3; Table 3). However, shoot dry weight, leaf number, and leaf area did not show significant differences between the two treatments. Under high blue PF (75B-25R\%), EOD-FR light treatment significantly increased the leaf area (34\%) and stem length (41\%) but did not affect shoot fresh weight, shoot dry weight, leaf number, and hypocotyl length. 


\section{Discussion}

Effects of white fluorescent light on intumescence injury of tomato plants. In the Expt. 1, tomato rootstock plants exhibited intumescences under LEDs but not under cool WFL. In tomato, intumescence injury occurs when UV-B is low or absent (Lang and Tibbitts, 1983; Rud, 2009). Therefore, in the present experiment, a small amount of UV-B light $\left(0.23 \mu \mathrm{mol} \cdot \mathrm{m}^{-2} \cdot \mathrm{s}^{-1} \mathrm{PF}, 0.33 \%\right.$ of $P P F$, Table 1) emitted from the cool WFL likely suppressed intumescence development. Wollaeger and Runkle (2014) reported a similar result for 'Early Girl' tomato, in which intumescence injury was nearly absent under WFL, whereas the plants developed intumescences under LEDs with 100\% red PF or LEDs with $25 \%$ blue, $25 \%$ green, and $50 \%$ red PF. Although the exact mechanism is not understood, UV-B may prevent intumescence development by inhibiting enlargement or division of parenchyma and epidermal cells. Low PF of UV-B is sufficient to affect the morphology of plants, such as reduction of stem elongation (Bertram and Lercari, 2000; Zuk-Golaszewska et al., 2003) and leaf area (Hectors et al., 2010; Lake et al., 2009; ZukGolaszewska et al., 2003). In Arabidopsis thaliana, UV including UV-B reduced leaf area by inhibiting cell enlargement (Hectors et al., 2010) or cell division (Lake et al., 2009). The inhibition of cell enlargement and cell division seems to be mediated through a UV-B photoreceptor UV RESISTANCE LOCUS 8 (UVR8) directly or by flavonoid accumulation which alters auxin homeostasis and inhibition of endoreduplication (Jansen et al., 2012; Peer and Murphy, 2007; Zenk and Müller, 1963).

Effects of EOD-FR light on intumescence injury of tomato plants. EOD-FR light mitigated intumescence injury on leaves and stem (Fig. 2; Table 2). Morrow (1987) and Morrow and Tibbitts (1988) showed that intumescence development was a red-FR reversible response, suggesting the involvement of phytochrome in regulation of intumescence development in tomato. Furthermore, using leaf disk of wild tomato, Morrow (1987) found that intumescence development was promoted with increasing red to FR light ratio or increasing phytochrome photoequilibrium $\left(P_{\mathrm{fr}} / P\right.$, where $\left.P=P_{\mathrm{r}}+P_{\mathrm{fr}}\right)$ and identified likely thresholds of $P_{\mathrm{fr}} / P$ highly promoting $(>0.5)$ or preventing intumescence development $(<0.42)$. In our present study, the light during the photoperiod was above the threshold level of promoting intumescence development (0.886), and EOD-FR light was below the threshold level of preventing intumescence development (0.113-0.122).

Table 2. Effects of end-of-day far-red (EOD-FR) light and blue photon flux ratio during the photoperiod on intumescence injury of 'Beaufort' tomato plants on the incidence of intumescences on stem (IMS) and leaf abscission (LA) (percentage of plants with IMS and LA). In Expt. 1, the tomato plants were grown under cool white fluorescent lamps (WFL treatment) or 10B-90R\% light-emitting diodes (LEDs) without or with high dose of EOD-FR light treatment $\left(67 \mathrm{mmol} \cdot \mathrm{m}^{-2}\right)$. In Expt. 2, the tomato plants were grown under $10 \mathrm{~B}-90 \mathrm{R} \%$ or $75 \mathrm{~B}-25 \mathrm{R} \%$ LEDs without or with varied daily dose of EOD-FR light treatment $\left(1-76 \mathrm{mmol} \cdot \mathrm{m}^{-2}\right)$. See Table 1 for the light treatment specifications.

\begin{tabular}{lrr}
\hline Light treatment & Incidence of IMS (\%) & Incidence of LA (\%) \\
\hline Expt. 1 & & $0.0 \mathrm{~b}$ \\
WFL & $0.0 \mathrm{~b}$ & $41.7 \mathrm{a}$ \\
10B-90R\% & $100.0 \mathrm{a}$ & $0.0 \mathrm{~b}$ \\
10B-90R\%-EOD-FR & $0.0 \mathrm{~b}$ & \\
Expt. 2 & & $54.2 \mathrm{a}$ \\
10B-90R\% & $62.5 \mathrm{a}$ & $0.0 \mathrm{~b}$ \\
10B-90R\%-FR1 & $0.0 \mathrm{c}$ & $4.2 \mathrm{~b}$ \\
10B-90R\%-FR2 & $0.0 \mathrm{c}$ & $0.0 \mathrm{~b}$ \\
10B-90R\%-FR4 & $0.0 \mathrm{c}$ & $0.0 \mathrm{~b}$ \\
10B-90R\%-FR9 & $0.0 \mathrm{c}$ & $0.0 \mathrm{~b}$ \\
10B-90R\%-FR76 & $0.0 \mathrm{c}$ & $8.3 \mathrm{~b}$ \\
75B-25R\% & $16.7 \mathrm{~b}$ & $0.0 \mathrm{~b}$ \\
75B-25R\%-FR4 & $0.0 \mathrm{c}$ & \\
\hline
\end{tabular}

Incidence values within the same column followed by different letters are significantly different by Tukey's wholly significant different test at $P \leq 0.05(\mathrm{n}=12$ or 24$)$.

Therefore, intumescence development was possibly induced during the photoperiod but the injury was mitigated by the EOD-FR light treatment followed by the dark period.

The exact mechanism for mitigation of intumescence injury by FR light is not known. One possible explanation may be based on the effect of FR light on mesophyll cell size and cell division. Low red to FR PF ratio is known to increase the leaf area but induce leaf thinning in many plant species (Barreiro et al., 1992; Boardman, 1977; Kasperbauer and Peaslee, 1973). Leaf thinning under low red to FR PF ratio occurs as a result of a decrease in the thickness of mesophyll parenchyma tissue (Barreiro et al., 1992; Sims and Pearcy, 1992) with associated reductions in cell size (cell length in the direction of leaf thickening) and cell number in palisade parenchyma (Hanson, 1917; Sims and Pearcy, 1992). Also, Liu et al. (2011) found that red light increased but FR light inhibited transport and biosynthesis of auxin in A. thaliana and tomato. Morrow (1987) indicated that intumescence development in tomato leaf disks under red light was possibly attributed to red light-induced cell wall loosening followed by turgor-driven cell enlargement. Therefore, EOD-FR light may have inhibited abnormal cell enlargement and intumescence development through auxin transport mediated by the light quality.

FR light increases plant leaf area for some species, a response likely to enhance lightforaging capacity under canopy (Franklin, 2008). In the present experiment, leaf area was increased by $34 \%$ to $97 \%$ by EOD-FR light treatment (Table 3). Therefore, the suppression of intumescence development by EOD-FR light may be due to improved plant water relations. That is, EOD-FR light may have relieved excessive turgor in mesophyll by increasing total leaf area and thereby whole plant transpiration rate.

Saturating FR dose for suppressing intumescence injury of tomato plants. There was little difference in the effect of EOD-FR on intumescence injury between the range of FR dose examined in this experiment (1.1$\left.76.0 \mathrm{mmol} \cdot \mathrm{m}^{-2} \cdot \mathrm{d}^{-1}\right)$. Morrow and Tibbitts (1988) suggested that the low fluence response (LFR) mediated by phytochrome was involved in intumescence development in tomato, because the red-FR reversibility

Table 3. Effects of end-of-day far-red (EOD-FR) light and blue photon flux ratio during photoperiod on growth and morphological parameters of 'Beaufort' tomato plants. Mean shoot fresh weight (FW), dry weight (DW), leaf number, leaf area, stem length, and hypocotyl length (HL). In Expt. 1, the tomato plants were grown under cool white fluorescent lamps (WFL treatment) or 10B-90R\% light-emitting diodes (LEDs) without or with high dose of EOD-FR light treatment $\left(67 \mathrm{mmol} \cdot \mathrm{m}^{-2}\right)$. In Expt. 2, the tomato plants were grown under $10 \mathrm{~B}-90 \mathrm{R} \%$ or $75 \mathrm{~B}-25 \mathrm{R} \%$ LEDs without or with EOD-FR light treatment $\left(4 \mathrm{mmol} \cdot \mathrm{m}^{-2}\right)$. See Table 1 for the light treatment specifications.

\begin{tabular}{|c|c|c|c|c|c|c|}
\hline Light treatment & Shoot FW (g) & Shoot DW (g) & Leaf number & Leaf area $\left(\mathrm{cm}^{2} /\right.$ plant $)$ & Stem length $(\mathrm{cm})$ & $\mathrm{HL}(\mathrm{cm})$ \\
\hline WFL & $1.22 \mathrm{a}$ & $0.079 \mathrm{a}$ & $4.8 \mathrm{a}$ & $58.5 \mathrm{a}$ & $8.8 \mathrm{c}$ & $2.8 \mathrm{c}$ \\
\hline $10 \mathrm{~B}-90 \mathrm{R} \%$ & $0.82 \mathrm{~b}$ & $0.060 \mathrm{a}$ & $3.6 \mathrm{~b}$ & $26.9 \mathrm{~b}$ & $11.9 \mathrm{~b}$ & $5.0 \mathrm{~b}$ \\
\hline 10B-90R\%-EOD-FR & $1.48 \mathrm{a}$ & $0.078 \mathrm{a}$ & $4.7 \mathrm{a}$ & $44.9 \mathrm{a}$ & $15.8 \mathrm{a}$ & $7.0 \mathrm{a}$ \\
\hline $10 \mathrm{~B}-90 \mathrm{R} \%$ & $0.64 \mathrm{c}$ & $0.050 \mathrm{~b}$ & $3.3 \mathrm{~b}$ & $20.8 \mathrm{~b}$ & $8.9 \mathrm{~b}$ & $4.2 \mathrm{~b}$ \\
\hline 10B-90R\%-FR4 & $1.29 \mathrm{a}$ & $0.078 \mathrm{a}$ & $4.0 \mathrm{a}$ & $40.9 \mathrm{a}$ & $14.3 \mathrm{a}$ & $5.4 \mathrm{a}$ \\
\hline $75 \mathrm{~B}-25 \mathrm{R} \%$ & $0.61 \mathrm{bc}$ & $0.047 \mathrm{~b}$ & $3.7 \mathrm{ab}$ & $25.6 \mathrm{~b}$ & $5.8 \mathrm{c}$ & $2.3 \mathrm{c}$ \\
\hline
\end{tabular}

Mean values in columns followed by different letters are significantly different by Tukey's honest significant test at $P \leq 0.05(\mathrm{n}=24$ or 12$)$. 


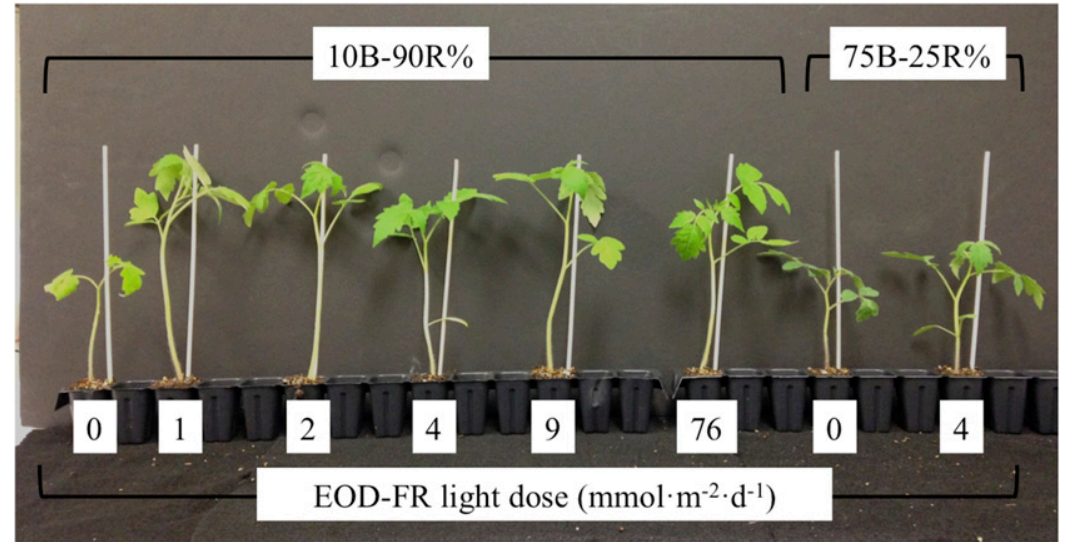

Fig. 3. 'Beaufort' tomato plants grown under $10 \mathrm{~B}-90 \mathrm{R} \%$ or $75 \mathrm{~B}-25 \mathrm{R} \%$ light-emitting diodes without or with varied daily dose of end-of-day far-red (EOD-FR) light treatment $\left(1-76 \mathrm{mmol} \cdot \mathrm{m}^{-2} \cdot \mathrm{d}^{-1}\right)(16 \mathrm{~d}$ after seeding) (Expt. 2).

demonstrated experimentally is a primary characteristic of LFR (Casal et al., 1998; Mancinelli, 1994). The dose (PF) required for saturation of LFR by red light is generally in a range from 0.001 to $10 \mathrm{mmol} \cdot \mathrm{m}^{-2}$. In our study, the inhibitory response against intumescence injury was likely saturated at a daily dose of less than $1 \mathrm{mmol} \cdot \mathrm{m}^{-2}$ (Fig. 2), which agrees with the aforementioned general range of saturation dose of LFR. Another well-known LFR is stem or hypocotyl elongation by EOD-FR light treatment, observed for many species (Blom et al., 1995; Decoteau et al., 1988; Kasperbauer and Peaslee, 1973). Chia and Kubota (2010) found that saturation dose of EOD-FR light for hypocotyl elongation was in the range of 5-15 $\mathrm{mmol} \cdot \mathrm{m}^{-2} \cdot \mathrm{d}^{-1}$, which was higher than our likely saturation dose for mitigation of intumescence injury (lower than $\left.1 \mathrm{mmol} \cdot \mathrm{m}^{-2} \cdot \mathrm{d}^{-1}\right)$. This may support the earlier observation by Morrow (1987) that there was a threshold of $P_{\mathrm{fr}} / P$ promoting intumescence development and may indicate that once the EOD $P_{\mathrm{fr}} / P$ meets the threshold, the following dark reversion of phytochrome to further reduce $P_{\mathrm{fr}} / P$ likely has no effect. The difference in saturation dose between hypocotyl elongation and intumescence injury mitigation suggests the possible difference between the thresholds of $P_{\mathrm{fr}} / P$. Instead of applying EOD-FR light, increasing FR to red light ratio during the photoperiod may also achieve the $P_{\mathrm{fr}} / P$ threshold for mitigation of intumescence injury.

Effects of high blue PF ratio during the photoperiod on intumescence injury of tomato plants. High blue PF ratio (75\%) during the photoperiod mitigated intumescence injury in 'Beaufort' tomato plants (Fig. 2; Table 2). Wollaeger and Runkle (2014) found that 'Early Girl' tomato seedlings grown under red and blue LEDs with $50 \%$ or $100 \%$ blue PF ratio $(50 \%$ or $0 \%$ red $\mathrm{PF}$ ratio) had nearly no intumescence injury, although most of the leaves developed intumescences under LEDs with $0 \%$ blue ( $100 \%$ red) PF. The mechanism by which high blue PF ratio inhibits intumescence development in tomato has not been known to elicit physiological plant responses mediated through blue light photoreceptors, cryptochrome or phototropin. Blue light also affects $P_{\mathrm{fr}} / P$; however, possible involvement of phytochrome in the inhibition of intumescence development under high blue PF ratio is unlikely in our present experiment, because, while the $P_{\mathrm{fr}} / P$ under high blue PF ratio (0.83) was lower than that under low blue PF ratio $(0.89)$, they are greater than the intumescence promoting threshold of $\approx 0.5$ reported by Morrow (1987).

Among cryptochrome- and phototropinmediated responses, two possible mechanisms could be considered to elucidate the effect of high blue PF ratio on intumescence development. One possible mechanism is by inhibiting cell enlargement and cell division (e.g., Dougher and Bugbee, 2004). Increasing blue PF inhibits stem elongation and leaf expansion (Hernández and Kubota, 2016; Nanya et al., 2012; Wollaeger and Runkle, 2014) through cryptochrome working together with phytochrome in many plant species (Ahmad and Cashmore, 1997; Folta and Spalding, 2001; Neff and Chory, 1998; Whitelam et al., 1993). Blue light-mediated inhibition of stem elongation and leaf expansion are reportedly caused by a decrease in cell enlargement and cell division (Cosgrove, 1981; Dale and Milthorpe, 1983; Dougher and Bugbee 2004; Kigel and Cosgrove, 1991; Shinkle and Jones, 1988; Van Volkenburgh et al., 1990). For example, Dougher and Bugbee (2004) found that in soybean, the increase in blue PF ratio from $<0.1 \%$ to $26 \%$ decreased internode length by reducing epidermal cell numbers in stems. They also found that the increase in blue PF ratio from $6 \%$ to $26 \%$ reduced soybean leaf area by decreasing epidermal cell size. Therefore, it may be possible that the high blue PF ratio inhibited the cell enlargement and thereby inhibited abnormal enlargement of cells causing intumescence injury in tomato.

Another possible mechanism to consider is the effect of high blue PF ratio on improved water relation in the plants. Traditionally discussed in the previous studies. Blue light is intumescence injury was believed to be caused by excessive turgor under high relative humidity, as shown for some plant species (Douglas, 1907; Eisa and Dobrenz, 1971; Metwally et al., 1970; Warrington, 1980). Several studies demonstrated that increasing blue PF ratio increased stomatal conductance $\left(g_{\mathrm{S}}\right)$ (Hernández and Kubota, 2016; Hogewoning et al., 2010; O'Carrigan et al., 2014; Savvides et al., 2012). For example, Hernández and Kubota (2016) showed that $g_{\mathrm{S}}$ increased linearly with increasing blue $\mathrm{PF}$ ratio from $0 \%$ to $100 \%$ in cucumber plants. The increased $g_{\mathrm{S}}$ under high blue PF ratio is reportedly mediated by phototropins (Boccalandro et al., 2012; Doi et al., 2004; Ohgishi et al., 2004), which involves enhancing the aperture of the stomatal pore, and cryptochromes, which involves increasing the stomatal density (Hogewoning at al., 2010; Ohgishi et al., 2004). Increased $g_{S}$ under high blue PF ratio may have increased transpiration rate and thereby possibly helped to reduce turgor in cells, resulting in the reduction of the severity of intumescence injury. Further study is needed to find the exact mechanism of inhibition of intumescence injury under high blue PF.

The blue PF required to suppress intumescence injury may be cultivar, species, or growing conditions specific. In our experiment, tomato rootstock plants 'Beaufort' (S. lycopersicum $\times S$. habrochitas $)$ grown under $75 \%$ blue PF ratio without EOD-FR light had moderate intumescence injury, while Wollaeger and Runkle (2014) showed that 'Early Girl' tomato (S. lycopersicum) plants grown under $50 \%$ blue PF ratio had nearly no intumescence injury. This difference in blue PF requirement to suppress intumescence injury between the two experiments is partly due to the genotypic difference of tomato associated with their native habitats. Solanum habrochitas is native in habitats ranging from central Peru to northern Ecuador at elevation from 200 to $3700 \mathrm{~m}$, higher than those reported for $S$. lycopersicum (0-2400 m) (Rick, 1973; Warnock, 1991). Therefore, $S$. habrochitas may be more susceptible to intumescence development than $S$. lycopersicum under radiation deficient in shorter wavelengths such as UV and blue light.

The blue PF requirement to suppress intumescence injury may be also dependent on plant growing conditions. In the present experiment, the tomato plants were placed under the light treatments after the radicles emerged ( $1 \mathrm{~d}$ after seeding), while Wollaeger and Runkle (2014) placed the plants under the light treatments after the cotyledons expanded (6-10 d after seeding). Until cotyledon expansion, the plants were grown in a glass-glazed greenhouse (E.S. Runkle, personal communication), which might have exposed the plants to some UV-B and potentially resulting in less severity of intumescence injury. Other environmental conditions such as relative humidity may also affect the severity of intumescence injury. 
Synergistic effect of high blue PF ratio during the photoperiod and EOD-FR light on intumescence injury of tomato plants. The combination of high blue $\mathrm{PF}$ ratio $(75 \%)$ during the photoperiod and EOD-FR light resulted in the maximum suppression of intumescence injury (Fig. 2; Table 2). This unique combination of high blue $\mathrm{PF}$ ratio and EOD-FR light provided a synergistic effect of each light treatment possibly through different photoreceptors. A high blue PF ratio may contribute to inhibition of intumescence development during the photoperiod and EOD-FR light may contribute inhibition of intumescence development during dark period. There may be an interaction between phytochrome, cryptochrome, and phototropin in inhibition of intumescence development. The interaction of cryptochrome or phototropin and phytochrome have been reported in some plant responses (Chory and Wu, 2001; Jaedicke et al., 2012).

Application of EOD-FR light and high blue PF for transplant production. In addition to mitigating intumescence injury, EODFR light after the photoperiod with low blue PF ratio $(10 \%)$ improved shoot fresh weight, shoot dry weight, leaf number, and leaf area up to the same level as those under WFL compared with the low blue PF ratio treatment without EOD-FR light (Table 3). This improvement was most likely because of the prevention of intumescence-induced leaf abscission by EOD-FR light (Table 2). The EOD-FR dose requirement to mitigate intumescence was as small as $1.1 \mathrm{mmol} \cdot \mathrm{m}^{-2} \cdot \mathrm{d}^{-1}$, which was obtained by $5.3 \mu \mathrm{mol} \cdot \mathrm{m}^{-2} \cdot \mathrm{s}^{-1} \mathrm{FR}$ irradiation for $3.3 \mathrm{~min}$. This low-intensity requirement of EOD-FR lighting is advantageous in applying in indoor transplant production facilities. However, under low blue PF ratio $(10 \%)$, EOD-FR light increased stem length and made tomato plants leggy, which is an undesirable morphology for transplant production (Fig. 3; Table 3). The high blue PF ratio combined with EOD-FR light suppressed the undesirable stem elongation caused by the EOD-FR light treatment (Fig. 3; Table 3).

\section{Conclusion}

EOD-FR light treatment alleviated intumescence injury of tomato plants grown under red and blue LEDs deficient in UV-B radiation. The mitigation response was saturated at a FR dose as low as $1.1 \mathrm{mmol} \cdot \mathrm{m}^{-2} \cdot \mathrm{d}^{-1}$. High blue PF ratio (75B-25R\%) during the photoperiod also mitigated intumescence injury. When the plants were grown under high blue PF ratio (75\%) during the photoperiod combined with EOD-FR light treatment, the intumescence injury was further and sufficiently inhibited. Also, under the combination of high blue PF ratio during the photoperiod and EOD-FR light treatment, undesirable stem elongation by EOD-FR light treatment was mitigated. Applying a small dose of EOD-FR light and high blue $\mathrm{PF}$ ratio during the photoperiod may provide a potential means to mitigate the problematic intumescence injury of tomato plants grown under LEDs or other light environment deficient in UV light. The synergistic effect of FR and blue was possibly through different photoreceptors and their interaction. Additional research must be conducted to determine the mechanisms.

\section{Literature Cited}

Ahmad, M. and A.R. Cashmore. 1997. The bluelight receptor cryptochrome 1 shows functional dependence on phytochrome A or phytochrome B in Arabidopsis thaliana. Plant J. 11: 421-427.

Balge, R.J., B.E. Struckmeyer, and G.E. Beck. 1969. Occurrence, severity and nature of oedema in Pelargonium hortorum Ait. J. Amer. Soc. Hort. Sci. 94:181-183.

Barreiro, R., J.J. Guiamet, J. Beltrano, and E.R. Montaldi. 1992. Regulation of the photosynthetic capacity of primary bean leaves by the red:far-red ratio and photosynthetic photon flux density of incident light. Physiol. Plant. 85:97-101.

Bertram, L. and B. Lercari. 2000. Evidence against the involvement of phytochrome in UVBinduced inhibition of stem growth in green tomato plants. Photosynth. Res. 64:107-117.

Boardman, N.K. 1977. Comparative photosynthesis of sun and shade plants. Annu. Rev. Plant Physiol. 28:355-377.

Boccalandro, H.E., C.V. Giordano, E.L. Ploschuk, P.N. Piccoli, R. Bottini, and J.J. Casal. 2012. Phototropins but not cryptochromes mediate the blue light-specific promotion of stomatal conductance, while both enhance photosynthesis and transpiration under full sunlight. Plant Physiol. 158:1475-1484.

Blom, T.J., M.J. Tsujita, and G.L. Roberts. 1995. Far-red at end of day and reduced irradiance affect plant height of Easter and Asiatic hybrid lilies. HortScience 30:1009-1012.

Casal, J.J., R.A. Sánchez, and J.F. Botto. 1998. Modes of action of phytochromes. J. Expt. Bot. 49:127-138.

Chia, P.-L. and C. Kubota. 2010. End-of-day farred light quality and dose requirements for tomato rootstock hypocotyl elongation. HortScience 45:1501-1506.

Chory, J. and D. Wu. 2001. Weaving the complex web of signal transduction. Plant Physiol. 125: $77-80$.

Cosgrove, D. 1981. Rapid suppression of growth by blue light: Occurrence, time course, and general characteristics. Plant Physiol. 67: 584-590.

Craver, J.K. 2014. The effects of UVB radiation on intumescence development and the characterization of lesions from physiological disorders on ornamental sweet potato (Ipomoea batatas), tomato (Solanum lycopersicum), and interspecific geranium (Pelargonium spp.). Kansas State Univ., Manhattan, MS Thesis.

Craver, J.K., C.T. Miller, K.A. Willia, and D.L. Boyle. 2014. Characterization and comparison of lesions on ornamental sweetpotato 'Blackie', tomato 'Maxifort', interspecific geranium 'Caliente Coral', and bat-faced cuphea 'Tiny Mice'. J. Amer. Soc. Hort. Sci. 139:603-615.

Dale, J.E. and F.L. Milthorpe. 1983. General features of the production and growth of leaves, p. 151-269. In: J.E. Dale and F.L. Milthorpe (eds.). The growth and functioning of leaves. Cambridge Univ. Press, Cambridge, MA.

Decoteau, D.R., M.J. Kasperbauer, D.D. Daniels, and P.G. Hunt. 1988. Plastic mulch color effects on reflected light and tomato plant growth. Sci. Hort. 34:169-175.
Demotes-Mainard, S., T. Péron, A. Corot, J. Bertheloot, J.L. Gourrierec, S. Pelleschi-Travier, L. Crespel, P. Morel, L. Huché-Thélier, R. Boumaza, A. Vian, V. Guérin, N. Leduc, and S. Sakr. 2016. Plant responses to red and far-red lights, applications in horticulture. Environ. Expt. Bot. 121: 4-21.

Doi, M., A. Shigenaga, T. Emi, T. Kinoshita, and K. Shimazaki. 2004. A transgene encoding a blue-light receptor, phot1, restores bluelight responses in the Arabidopsis phot1 phot2 double mutant. J. Expt. Bot. 55:517-523.

Dougher, T.A.O. and B. Bugbee. 2004. Long-term blue light effects on the histology of lettuce and soybean leaves and stems. J. Amer. Soc. Hort. Sci. 129:467-472.

Douglas, E.G. 1907. The formation of intumescences on potato plants. Bot. Gaz. 43:233-250.

Eisa, H.M. and A.K. Dobrenz. 1971. Morphological and anatomical aspects of oedema in eggplants (Solanum melongena L.). J. Amer. Soc. Hort. Sci. 96:766-769.

Fankhauser, C. and J.J. Casal. 2004. Phenotypic characterization of a photomorphogenic mutant. Plant J. 39:747-760.

Folta, K.M. and E.P. Spalding. 2001. Opposing roles of phytochrome A and phytochrome B in early cryptochrome-mediated growth inhibition. Plant J. 28:333-340.

Franklin, K.A. 2008. Shade avoidance. New Phytol. 179:930-944.

Hanson, H.C. 1917. Leaf-structure as related to environment. Amer. J. Bot. 4:533-560.

Hectors, K., E. Jacques, E. Prinsen, Y. Guisez, J.-P. Verbelen, M.A.K. Jansen, and K. Vissenberg. 2010. UV radiation reduces epidermal cell expansion in leaves of Arabidopsis thaliana. J. Expt. Bot. 61:4339-4349.

Hendricks, S.B. and H.A. Borthwick. 1967. The function of phytochrome in regulation of plant growth. Proc. Natl. Acad. Sci. USA 58: 2125-2130.

Hendricks, S.B., W.L. Butler, and H.W. Siegelman. 1962. A reversible photoreaction regulating plant growth. J. Phys. Chem. 66:2550-2555.

Hernández, R. and C. Kubota. 2016. Physiological responses of cucumber seedlings under different blue and red photon flux ratios using LEDs. Environ. Expt. Bot. 121:66-74.

Hogewoning, S.W., G. Trouwborst, H. Maljaars, H. Poorter, W. van Ieperen, and J. Harbinson. 2010. Blue light dose-responses of leaf photosynthesis, morphology, and chemical composition of Cucumis sativus grown under different combinations of red and blue light. J. Expt. Bot. 61:3107-3117.

Jaedicke, K., A.L. Lichtenthäler, R. Meyberg, M. Zeidler, and J. Hughes. 2012. A phytochromephototropin light signaling complex at the plasma membrane. Proc. Natl. Acad. Sci. USA 109:12231-12236.

Jansen, M.A.K., A.M. Coffey, and E. Prinsen. 2012. UV-B induced morphogenesis-Four players or a quartet? Plant Signal. Behav. 7:1185-1187.

Kasperbauer, M.J. and D.E. Peaslee. 1973. Morphology and photosynthetic efficiency of tobacco leaves that received end-of-day red and far red light during development. Plant Physiol. $52: 440-442$

Kigel, J. and D.J. Cosgrove. 1991. Photoinhibition of stem elongation by blue and red light. Plant Physiol. 95:1049-1056.

Lake, J.A., K.J. Field, M.P. Davey, D.J. Beerling, and B.H. Lomax. 2009. Metabolomic and physiological responses reveal multi-phasic acclimation of Arabidopsis thaliana to chronic 
UV radiation. Plant Cell Environ. 32:13771389.

Lang, S.P., B. E. Struckmeyer, and T.W. Tibbitts. 1983. Morphology and anatomy of intumescence development on tomato plants. J. Amer. Soc. Hort. Sci. 108:266-271.

Lang, S.P. and T.W. Tibbitts. 1983. Factors controlling intumescence development on tomato plants. J. Amer. Soc. Hort. Sci. 108:93-98.

La Rue, C.D. 1933. Intumescences on poplar leaves. I. Structure and development. Amer. J. Bot. 20:1-17.

Liu, X., J.D. Cohen, and G. Gardner. 2011. Lowfluence red light increases the transport and biosynthesis of auxin. Plant Physiol. 157:891-904.

Mancinelli, A.L. 1994. The physiology of phytochrome action, p. 235-269. In: R.E. Kendrick and G.H.M. Kronenberg (eds.). Photomorphogenesis in plants. 2nd ed. Kluwer Academic Publishers, Dordrecht, The Netherlands.

Mancinelli, A.L., H.A. Borthwick, and S.B. Hendricks. 1966. Phytochrome action in tomato seed germination. Bot. Gaz. 127:1-5.

Massa, G.D., H.-H. Kim, R.M. Wheeler, and C.A. Mitchell. 2008. Plant productivity in response to LED lighting. HortScience 47:1951-1956.

Metwally, A.W., G.E. Beck, and B.E. Struckmeyer. 1970. The role of water and cultural practices on oedema of Pelargonium hortorum Ait. J. Amer. Soc. Hort. Sci. 95:808-813.

Morrow, R.C. 1987. Environmental factors regulating intumescence development (oedema) in tomatoes. Univ. Wisconsin, Madison, PhD Diss.

Morrow, R.C. and T.W. Tibbitts. 1988. Evidence for involvement of phytochrome in tumor development on plants. Plant Physiol. 88:1110-1114.

Nanya, K., Y. Ishigami, S. Hikosaka, and E. Goto. 2012. Effects of blue and red light on stem elongation and flowering of tomato seedlings. Acta Hort. (956):261-266.

Neff, M.M. and J. Chory. 1998. Genetic interactions between phytochrome A, phytochrome B, and cryptochrome 1 during Arabidopsis development. Plant Physiol. 118:27-35.

O'Carrigan, A., M. Babla, F. Wang, X. Liu, M. Mak, R. Thomas, B. Bellotti, and Z.-H. Chen.
2014. Analysis of gas exchange, stomatal behaviour and micronutrients uncovers dynamic response and adaptation of tomato plants to monochromatic light treatments. Plant Physiol. Biochem. 82:105-115.

Ohgishi, M., K. Saji, K. Okada, and T. Sakai. 2004. Functional analysis of each blue light receptor, cry 1 , cry 2 , phot 1 , and phot 2 , by using combinatorial multiple mutants in Arabidopsis. Proc. Natl. Acad. Sci. USA 101:2223-2228.

Peer, W.A. and A.S. Murphy. 2007. Flavonoids and auxin transport: Modulators or regulators? Trends Plant Sci. 12:556-563.

Petitte, J.M. and D.P. Ormrod. 1986. Factors affecting intumescence development on potato leaves. HortScience 21:493-495.

Pinkard, E., W. Gill, and C. Mohammed. 2006. Physiology and anatomy of lenticel-like structures on leaves of Eucalyptus nitens and Eucalyptus globulus seedlings. Tree Physiol. 26:989-999.

Rangarajan, A. and T.W. Tibbitts. 1994. Exposure with far-red radiation for control of oedema injury on 'Yale' ivy geranium. HortScience 29:38-40.

Rick, C.M. 1973. Potential genetic resources in tomato species: Clues from observations in native habitats, p. 255-269. In: A.M. Srb (ed.). Genes, enzymes, and populations. Plenum, New York, NY.

Rud, N.A. 2009. Environmental factors influencing the physiological disorders of edema on ivy geranium (Pelargonium peltatum) and intumescences on tomato (Solanum lycopersicum). Kansas State Univ., Manhattan, MS Thesis.

Sager, J.C., W.O. Smith, J.L. Edwards, and K.L. Cyr. 1988. Photosynthetic efficiency and phytochrome photoequilibria determination using spectral data. Trans. Amer. Soc. Agr. Eng. 31:1882-1889.

Savvides, A., D. Fanourakis, and W. van Ieperen. 2012. Co-ordination of hydraulic and stomatal conductances across light qualities in cucumber leaves. J. Expt. Bot. 63:1135-1143.

Shinkle, J.R. and R.L. Jones. 1988. Inhibition of stem elongation in Cucumis seedlings by blue light requires calcium. Plant Physiol. 86:960-966.
Siegelman, H.W., B.C. Turner, and S.B. Hendricks. 1966. The chromophore of phytochrome. Plant Physiol. 41:1289-1292.

Sims, D.A. and R.W. Pearcy. 1992. Response of leaf anatomy and photosynthetic capacity in Alocasia macrorrhiza (Araceae) to a transfer from low to high light. Amer. J. Bot. 79:449455.

Smith, H. 1994. Sensing the light environment: The functions of the phytochrome family, p. 377 416. In: R.E. Kendrick and G.M.H. Kronenberg (eds.). Photomorphogenesis in plants. 2nd ed. Kluwer Academic Publishers, Dordrecht, The Netherlands.

Van Volkenburgh, E., R.E. Cleland, and M. Watanabe. 1990. Light-stimulated cell expansion in bean (Phaseolus vulgaris L.) leaves. II. Quantity and quality of light required. Planta 182:77-80.

Warnock, S.J. 1991. Natural habitats of Lycopersicon species. HortScience 26:466-471.

Warrington, I.J. 1980. Humidity-induced gall formation on Eucalyptus species. Aust. For. Res. 10:185-189.

Wetzstein, H.Y. and J.J. Frett. 1984. Light and scanning electron microscopy of intumescences on tissue-cultured, sweetpotato leaves. J. Amer. Soc. Hort. Sci. 109:280-283.

Whitelam, G.C., E. Johnson, J. Peng, P. Carol, M.L. Anderson, J.S. Cowl, and N.P. Harberd. 1993. Phytochrome A null mutants of Arabidopsis display a wild-type phenotype in white light. Plant Cell 5:757-768.

Wollaeger, H.M. and E.S. Runkle. 2014. Growth of impatiens, petunia, salvia, and tomato seedlings under blue, green, and red light-emitting diodes. HortScience 49: 734-740.

Zenk, M.H.M. and G. Müller. 1963. In vivo destruction of exogenously applied indolyl-3acetic acid as influenced by naturally occurring phenolic acids. Nature 200:761-763.

Zuk-Golaszewska, K., M.K. Upadhyaya, and J. Golaszewski. 2003. The effect of UV-B radiation on plant growth and development. Plant Soil Environ. 49:135-140. 